\title{
T-Cell Surface Protein Tactile
}

National Cancer Institute

\section{Source}

National Cancer Institute. T-Cell Surface Protein Tactile. NCI Thesaurus. Code C157303.

T-cell surface protein tactile (585 aa, $\sim 66 \mathrm{kDa}$ ) is encoded by the human CD96 gene. This protein may play a role in immunoregulation. 